\title{
VIEWPOINT
}

\section{Greening critical care}

\author{
Martin Chapman*1 and Alison Chapman²
}

\begin{abstract}
Climate change and environmental stewardship are phrases that have been defining the past few decades and promoting change in our societies. The sensitivities of intensive care as a specialty make the process of greening an intensive care unit a challenge, but not one that is insurmountable. This paper discusses opportunities for critical care to reduce its environmental impact and provide a framework change. The article includes suggestions of what can be done as an individual, as a unit and as a hospital. Generally, practices in critical care are accepted without questioning the environmental consequences. We believe it is time for change, and critical care should give environmental stewardship a higher priority.
\end{abstract}

\section{Introduction}

Many have argued that the risks to health from climate change are overwhelmingly negative. At the conclusion of the United Nations Climate Change Conference in Copenhagen (COP15), which took place in December 2009 , there was no agreed-upon plan of action that would avoid a critical $2 \%$ rise in greenhouse gas (GHG) emissions globally. Our international leaders did not step up to the plate; rather, they produced an Accord [1] that will neither solve the problem nor appease the critics [2]. The implications for health [3-5], in light of this, are similar to implications for the economy [6] and the earth's natural systems - they are dire.

Our viewpoint is that it is better to be part of the solution than part of the problem, even if there is a dearth of evidence stating that any of the described actions will generate a measureable outcome. When using the term green, we are referring to practices and policies that do not negatively affect our environment. It is hoped that this paper will map out ways to green up an intensive care unit (ICU) and reduce the effect of environmental toxins on our patients, with suggestions targeted at

*Correspondence: Martin.chapman@sunnybrook.ca

'Department of Critical Care Medicine, Sunnybrook Health Sciences Centre,

Rm D108, 2075 Bayview Avenue, Toronto, Ontario, Canada, M4N 3M5

Full list of author information is available at the end of the article individuals and their institutions. Although sustainable critical care may sound like an oxymoron to many of us, we cannot ignore our responsibilities on the basis that greening an ICU is too difficult. There are steps that can be taken at all levels, setting an example to influence our collective behaviour. If an ICU can go green then there is little excuse for the rest of the hospital not to follow suit.

The gauntlet is thrown down.

\section{Background}

ICUs are not, in our experience, at the forefront of sustainable environmental management. Possibly the only published mention of intensive care and the environment was when, during the Copenhagen Conference, India's Environment Minister said that the Kyoto pact was in 'Intensive Care, if not dead' when negotiations on extending the pact had stalled [7].

We are not suggesting that patient care should be in any way compromised in order to improve the environmental status of your ICU. But there are measures that can be undertaken by any ICU that can, for example, reduce GHG emissions or minimise patient exposure to toxins. What follows is a description of domains to be considered and a framework to examine and implement change in an ICU.

\section{Areas of focus}

There are at least four areas to consider - consumption, waste, toxins and the personal footprint of staff (Figure 1).

The mantra in the literature is the Three Rs: reduce, reuse and recycle. Application of these principles throughout the ICU is important to reveal hidden opportunities.

\section{Consumption}

\section{Sustainable purchasing}

Healthcare facilities purchase thousands of different products requested by dozens of different departments. Often unknowingly, hospitals may purchase items that are toxic to workers or patients, or have serious environmental impacts. Environmentally preferable purchasing is a system that identifies and mitigates these problems by adopting a more responsible purchasing strategy with the following elements [8]: reducing transportation requirements; encouraging sustainable packaging; avoiding single-use products if a suitable alternative exists (impact of reprocessing multi-use products must be 


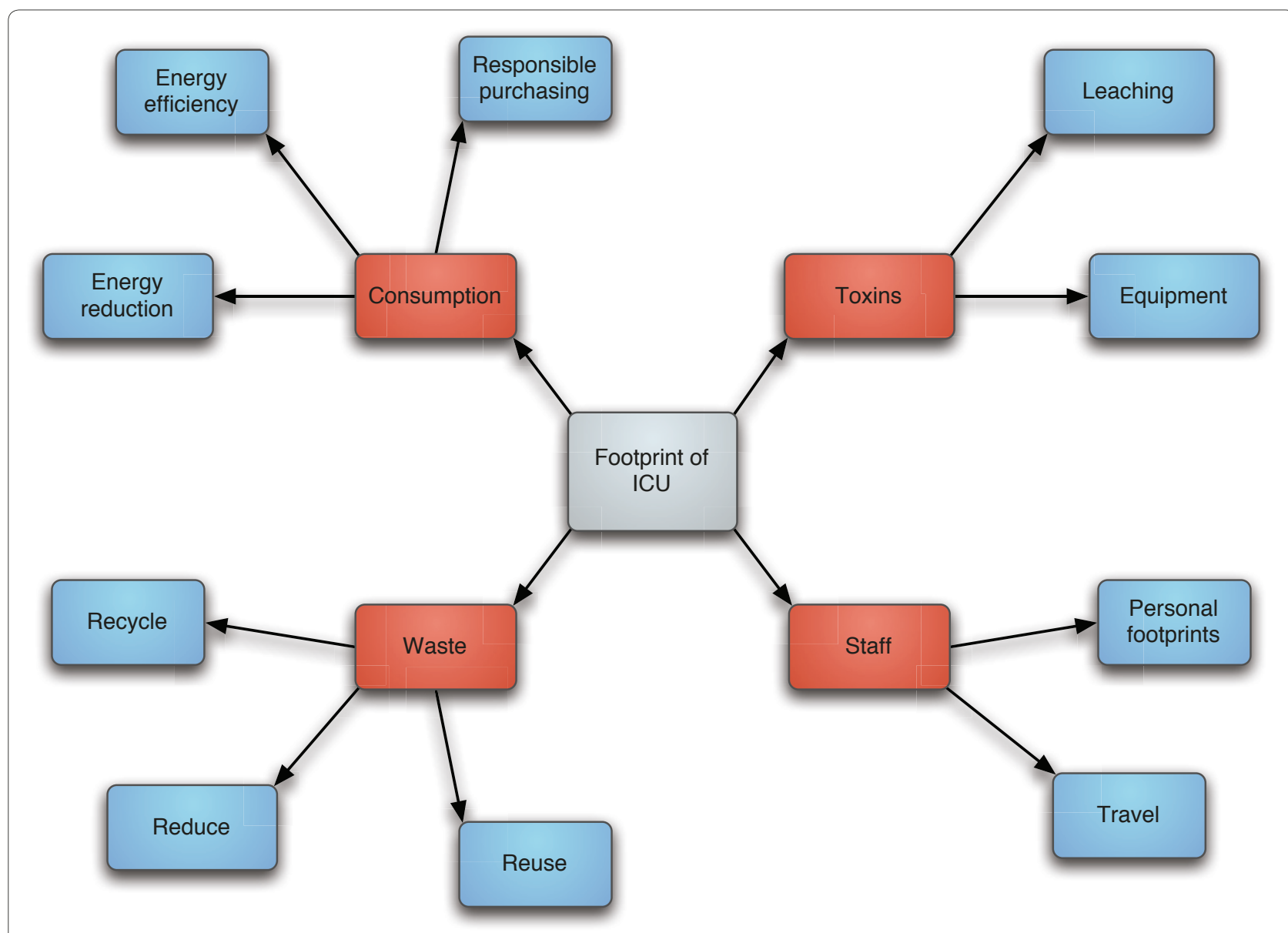

Figure 1. Reducing the environmental impact of an intensive care unit: four focus areas.

factored into the decision); avoiding products with potential toxins that are used in the manufacturing process (for example, mercury, di(2-ethylhexyl)phthalate, bisphenol A) (Table 1); and choosing products made with recyclable or degradable materials.

The contribution that pharmaceuticals make to the overall carbon footprint of a health system is rarely appreciated. In the United Kingdom, it is estimated that $22 \%$ of the total carbon emissions from the National Health Service can be attributed to pharmaceuticals [9]. Changing this at a local level is clearly limited but action can be taken by advocating for the unit pharmacy to source from companies that have a legitimate green policy, which many are adopting [10]. It is only when contracts are not renewed that the competitive culture will alter the manufacturing priorities [11]. Various agencies have produced tools to benchmark manufacturers and aid your local environmentally preferable purchasing system [12].

\section{Reprocessing}

In health facilities management, reprocessing refers to the rendering of used devices (multiple-use or single-use devices) or unused opened devices to be patient ready. This concept incorporates all aspects of the Three Rs and it has gained attention in the medical literature and by governments keen to explore every strategy for efficient use of resources [13]. The motivation here is twofold: reusing devices leads to a reduction in the output of waste destined for landfill sites and to a reduction in operational costs for devices. The reprocessed devices are normally sold back to the healthcare provider at 40 to $60 \%$ of the original cost. One of the larger independent reprocessing companies in the United States has claimed that their activity diverted over 2,000 tons of waste from landfill during 2008. The savings from this waste management and the reduced device costs amounted to over US\$130 million during that year [14].

The antagonists of this strategy, however, quote the potential risks to patient safety. These mainly include contamination/infection, device malfunction and regulation of the industry. With regards to safety, the US Food and Drug Administration has issued supportive guidelines that, along with the Medical Device User Fee and Modernization Act of 2002, formed their federal 
Table 1. Known toxins from products commonly found in the critical care environment [24]

\begin{tabular}{|c|c|c|c|}
\hline \multirow[t]{2}{*}{ Mercury } & Thermometer & Neurotoxin & Digital and dot-matrix \\
\hline & Sphymomanometers & & Aneroid, nonlatex \\
\hline \multirow[t]{2}{*}{ Brominated flame retardants } & Electronic equipment & $\begin{array}{l}\text { Neurobehavioural toxicity, thyroid } \\
\text { hormone disruption }\end{array}$ & Nonhalogenated retardants \\
\hline & Patient bedding & & \\
\hline Cadmium & Biohazard bags & & Heavy-metal free \\
\hline Cleaning agents & & $\begin{array}{l}\text { Excess water and cleaning solution } \\
\text { use, occupational injury }\end{array}$ & Microfiber mops and cloths \\
\hline DEHP & $\begin{array}{l}\text { Blood bags, urinary collection kits, } \\
\text { intravenous tubing, dialysis containers, } \\
\text { vascular catheters, feeding tubes and } \\
\text { enteral feeding pump kits, TPN bags, } \\
\text { chest drain catheters }\end{array}$ & $\begin{array}{l}\text { Hormone disruption (reproductive } \\
\text { toxicant to vulnerable populations; } \\
\text { for example, neonates) }\end{array}$ & DEHP-free PVC materials \\
\hline Glutaraldehyde & General disinfectants and sterilants & Respiratory irritant, skin irritant & $\begin{array}{l}\text { Ortho-phthalaldehyde, hydrogen peroxide, } \\
\text { enclosed cleaning technologies }\end{array}$ \\
\hline Latex & Rubber products & Allergen & Nitrile-rubber, neoprene (contains chlorine) \\
\hline \multirow[t]{3}{*}{ PVC } & $\begin{array}{l}\text { Mattress covers, fluid bags, tubing, } \\
\text { electrocardiography electrodes }\end{array}$ & $\begin{array}{l}\text { During manufacture and disposal, } \\
\text { hazardous chemicals (for example, } \\
\text { mercury, chlorine, dioxins) are released }\end{array}$ & Polyurethane, polyolefin, silicone \\
\hline & Patient ID bracelets & & Nonstretch polyester \\
\hline & $\begin{array}{l}\text { Office supplies (for example, vinyl } \\
\text { binders, colour-coated paper-clips) }\end{array}$ & & Pressboard, polypropylene \\
\hline Lead & Lead apron $X$-ray shielding & & Lead and PVC-free aprons \\
\hline
\end{tabular}

DEHP, di(2-ethylhexyl)phthalate; PVC, polyvinylchloride; TPN, total parenteral nutrition. Taken from information provided at http://www.noharm.org/us_canada/ issues/toxins/.

legislation. The foundation for this is outlined in a report from the US Government Accountability Office [15]. The US Government Accountability Office examined the reported adverse events from devices between 2003 and 2005. Of the 434 adverse events, 65 were in reprocessed devices and all were similar in nature to those in new devices. The US Food and Drug Administration stated that the available data 'does not indicate that reprocessed devices currently in use pose an increased safety threat.' Canada has yet to offer definitive guidance, with some voices calling for a complete ban on resterilisation [16]. European countries vary widely in their approach, from a fully regulated system in Germany to being forbidden in France. In the United Kingdom, the Medicines \& Healthcare Regulatory Agency has issued a statement warning against reuse of single-use devices [17], citing the reasons of cross-contamination and particularly prion exposure. Further investigation in this area is clearly essential with large gains to be made if a consensus could be achieved.

\section{Health records}

Although converting a paper-based ICU to one of electronic health records may seem a solid move for your green profile, it is an example of how hidden carbon costs may outweigh the more obvious gains in waste reduction. Although there are few data on this area specifically, a review of health informatics estimated that the power consumption for a completely electronic health record system in a large German academic medical centre amounted to $1.7 \mathrm{MW}$; enough to heat 170 houses in winter [18]. This does not even include the carbon footprint for procuring the infrastructure. The compromise is to regard the information technology solution as an integral part of a unit's footprint, with careful planning and integration required to achieve mutual offsets. There are educational programmes on sustainable information technology that are emerging and will assist with these issues [19].

\section{Energy obligations}

Hospitals are heavy users of energy. In Ontario, Canada, $47.3 \%$ of the running costs of hospitals can be attributed to their energy supplies, and $50 \%$ of those costs can be attributed to electricity [20]. The magnitude of this suggests that there could be opportunities to improve on your facility's efficiency. The mean consumption for Ontario hospitals is $2.59 \mathrm{GJ} / \mathrm{m}^{2}$. This can be compared with Swedish hospitals that, when adjusted for similar operating conditions, had a mean consumption of $1.3 \mathrm{GJ} / \mathrm{m}^{2}$ [21]. Understanding how energy is used and identifying measures for improving energy efficiency of existing facilities are key steps.

As an example of a large-scale innovation, Harvard Medical School has incorporated an online energy meter 
for its various buildings that provides a continuous readout of its energy consumption and trending charts since the programme started [22]. This can identify energy-rich times and activities and can provide powerful feedback to encourage important changes in behaviour.

The ICU must become responsible for its energy conservation. The interventions chosen can be of varying degrees of complexity, but many require little change:

- Choose EnergyStar-compliant electronic equipment (for example, patient bedside monitors, televisions, refrigerators, computers).

- Set computers to stand-by mode when not in use (switching to a screensaver mode does not reduce consumption, and may even increase it with heavy graphics processing).

- Use timers and power bars for equipment that use a standby function to reduce their consumption to zero in quiet periods; use sensors to control lighting in areas of intermittent traffic and variable daylight.

- Use temperature control that is flexible in both timing and isolating geographical areas.

\section{Building specifications}

Acknowledging that brand new facilities are a rarity, even the more restrained retrofit projects for ICUs can incorporate many building innovations. Hospital construction now has certification systems, such as the Leadership in Energy and Environmental Design for Healthcare Green Building Rating System [23], to verify that they are designed and built using strategies aimed at improved performance across a wide range of environmental metrics. There are certain key features that set a certified building project apart: sustainable site features (for example, preserving local ecologies); aggressive energy savings for building type; indoor environmental quality (low volatile organic compound emissions, thermal comfort, daylight, views); reduced impacts from choice of materials; water use reduction (for example, low-flow taps, nozzles and toilets); green housekeeping; and an alternative transportation incentive programme.

\section{Waste}

\section{Waste reduction}

In the United States, healthcare is the second highest contributor to landfill and incinerators, producing almost 6,000 tonnes of waste a day [21]. It is estimated that 80 to $85 \%$ of this waste is nonhazardous. Many of the sterilised items have some paper component to their packaging. Point-of-use separation is probably the easiest strategy and requires a practical choice of receptacle and clear guidance. As always, education needs to be reinforced by feedback and incentives. This can be aided by implementing waste audits with rolling feedback of the ratio of diverted waste for recycling.
There is an obligatory amount of waste from critical care areas that is biohazard material and sharps. There are no current options for sustainable disposal of this type of waste although the handling process is amenable to a green review. There are waste management services that use recyclable containers to transfer the waste.

\section{Toxins}

Modern manufacturing can involve the use of substances with toxic profiles, which either are incorporated in the product or are used or released in the manufacturing process. These substances can be present unknowingly to patients or their carers. Table 1 shows some of the more common substances that may be present in an ICU [24]. The connections between these substances and harmful human effects vary in their level of evidence. Even in the presence of only animal studies of toxicity, however, there is a philosophical argument for taking a conservative stance, cautioning their use, especially when alternative products are available. Where the concern is over harmful byproducts in the manufacturing process, choosing alternative materials represents a responsible stand to mitigate environmental harm.

As one example, di(2-ethylhexyl)phthalate is a plasticiser found in polyvinylchloride products such as feeding tubes, dialysis and extracorporeal membrane oxygenator tubing and blood product bags [25]. In animal studies this plasticiser has been shown to induce cancer of the liver, developmental and reproductive organ abnormalities, and renal and lung toxicity. Although to date there are no data demonstrating harm in adults, there are highrisk groups in whom it would be prudent to avoid exposure [26]. These may include critically ill neonates, infants and pregnant women with male foetuses. Adult extracorporeal membrane oxygenation may also be a high-risk procedure for exposure. As alternatives, there are cost-effective di(2-ethylhexyl)phthalate-free products.

\section{Staff}

There are areas in our personal lives that are associated with high carbon dioxide emissions. These tend to include energy consumption, transportation, food choice, general material consumption and waste [26]. At its simplest, a carbon footprint calculator, such as that from the World Wildlife Fund [27], can help an individual grasp their personal impact and develop a strategy for GHG reduction.

Measures promoting energy conservation often do not require costly change, and a personal checklist is found in Table 2 (adapted from [28]). In Canada, transportation (road, rail, air, marine) accounts for about $21 \%$ of the country's GHG emissions [29] and as such is an obvious area to tackle. Staff can be encouraged to take alternative modes of transportation for their daily commutes at least 
Table 2. Personal energy-saving checklist

Switch to energy-saving bulbs

Turn off appliances and lights (stand-by is not as energy efficient as off)

Wash your clothes at $30^{\circ} \mathrm{C}$ or lower ${ }^{\mathrm{a}}$

Turn down your thermostat: for every $1^{\circ} \mathrm{C}$ you lower your thermostat, you will not only cut your carbon emissions by an average of $330 \mathrm{~kg} / \mathrm{year}$ but could also save on your heating bill

Insulate - walls, floors, loft space, tanks, windows, and so forth

Install energy-saving appliances

Switch to a green energy provider: one that uses renewable sources such as solar, wind and wave energy

Generate your own energy: solar panels, solar photovoltaic cells, ground source heat, and so forth

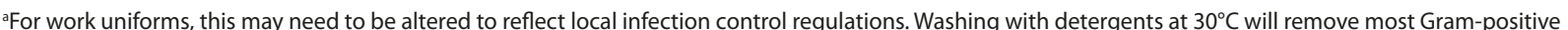
microorganisms, including all methicillin-resistant Staphylococcus aureus; and a 10-minute wash at $60^{\circ} \mathrm{C}$ is sufficient to remove almost all microorganisms. In tests, only $0.1 \%$ of any Clostridium difficile spores remained. Microbiologists carrying out the research advise that this level of contamination on uniforms and workwear is not a cause for concern [34].

once a month (car-pooling, cycling, public transit or walking) [30].

\section{Material purchase and disposal}

Every manufactured item that we purchase has an environmental impact. An animated documentary, the Story of Stuff, concludes that purchasing less may ultimately be the best option. But when we do buy stuff our choices can direct market forces to effect positive environmental change. An illuminating survey of marketing practice is the Seven Sins of Greenwashing [31], which explains that not all products in the green aisle at the grocery store are beneficial for the environment and provides a more detailed look at the growing number of unregulated green logos.

\section{Critical care academia}

One attendee at a previous European Respiratory Society conference made the observation that the 17,000 delegates generated 4,000 tonnes of carbon dioxide from travelling, compounded by the paper consumed in the abstract book and flyers in the free satchel [32]! Using sustainable means of transport for meetings and conferences, replacing meetings by teleconferencing and avoiding wasteful use of media for disseminating work are several changes that can be made. The minimum should be to ensure the mandatory use of two-sided printing on recycled paper.

\section{Where to begin}

The best place to start is by engaging colleagues and staff of the unit. Without their support, success - even incremental success - is unlikely.

\section{Practical action}

Figure 2 suggests some steps that can be taken by any unit to establish an agenda of environmental stewardship.

\section{Summing up}

There is no magic wand to reduce GHG emissions. Any serious effort requires resolve, irrespective of whether we run an ICU or work at the bedside. The fact that so much of our life is spent in our workplace, in turn, offers unique opportunities for promoting communal effort, and sets it up as an ideal setting for change [33]. Thankfully, there is a movement all over the world discovering that hospital energy use can be drastically reduced, that polyvinylchloride and phthalates are not necessary for patient care and that food can be sustainably sourced.

Therefore, in an ICU - although connections with climate change may be subtle for many of us - the responsibility still lies with those contributing to the problem, and requires us to participate in the solution.

\section{Useful links}

Sustainable Development Unit, NHS

[http://www.sdu.nhs.uk/]

Sustainable Hospitals

[http://www.sustainablehospitals.org]

Healthcare Without Harm [http://www.noharm.org/]

Campaign for Greener Healthcare

[http://www.greennhs.org/]

The Climate Connection

[http://theclimateconnection.org/]

World Watch - Vision for a Sustainable World

[http://www.worldwatch.org/]

US Environmental Protection Agency - Climate Change: What You can do at the Office

[http://www.epa.gov/climatechange/wycd/office.html] Harvard Medical School Green Program

[http://green.harvard.edu/hms/green-program]

Canadian Coalition of Green Healthcare

[http://www.greenhealthcare.ca/index.htm]

David Suzuki Foundation [http://www.davidsuzuki.org/] 

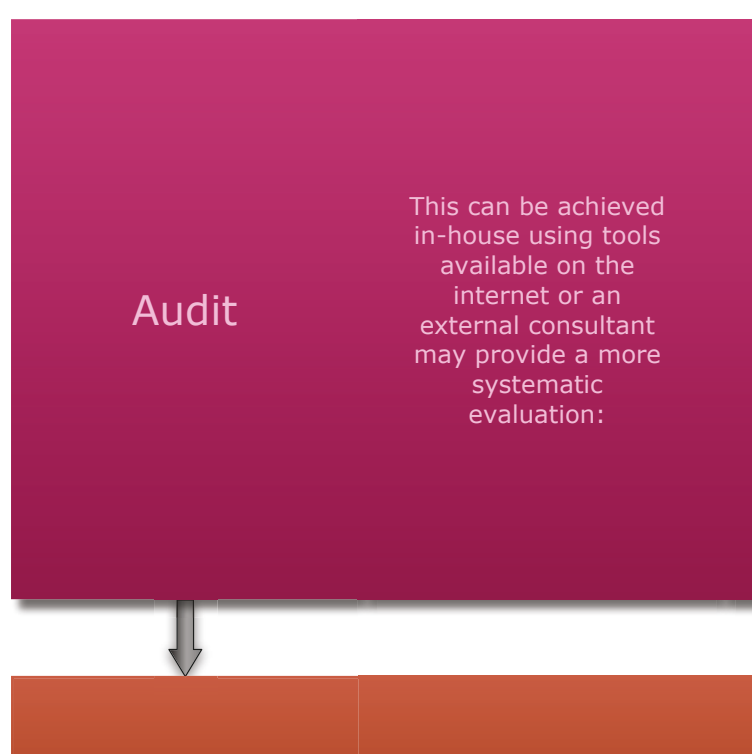

Education

"Green Teams"

It is vital that this group be formed of members from all

Multi- aspects of the ICU, disciplinary

Team including

Housekeeping, Facilities

Management Infection Control, Pharmacy, Allied Healthcare, Nursing and Physicians.
- Waste management - current level of recycling

- Evaluate inventory of supplies

- Suppliers' commitment to a green strategy

- Disposable versus reusable alternatives

- Specific toxic substance prevalence in the units e.g. DHEP, BPA, mercury

- Staff transport - carbon footprint for workforce travel

- Energy consumption - e.g. light fixtures, electronic equipment

- Water use

- Staff awareness level - an indicator for the appreciation of the issues and their priority will aid in assess the impact of any educational strategy

- Engage staff by challenging them to calculate their own carbon footprint

- Introduce concept of The Three R's

- Feedback of unit audits to increase awareness of our current level of "greenness"

- Educational projects around the specific goals staff could achieve

- Printed material for staff and public (for ICU waiting / family rooms)

- Dashboard of measured outcomes

- Identify areas for change in the short term

- Recycling and garbage reduction including separation of garbage at the bedside, recycling office supplies (including batteries, toner cartridges)

- Transport - organise car pooling scheme, promote alternative means of transport (provide showering and changing facilities)

- Put 'Greening' as standing item on agenda of operational meetings to assess all decisions for impact

- Produce local policy on reprocessing of single-use devices

- Introduce a responsible purchasing policy

- Power OFF promotion for lighting and standby power conservation

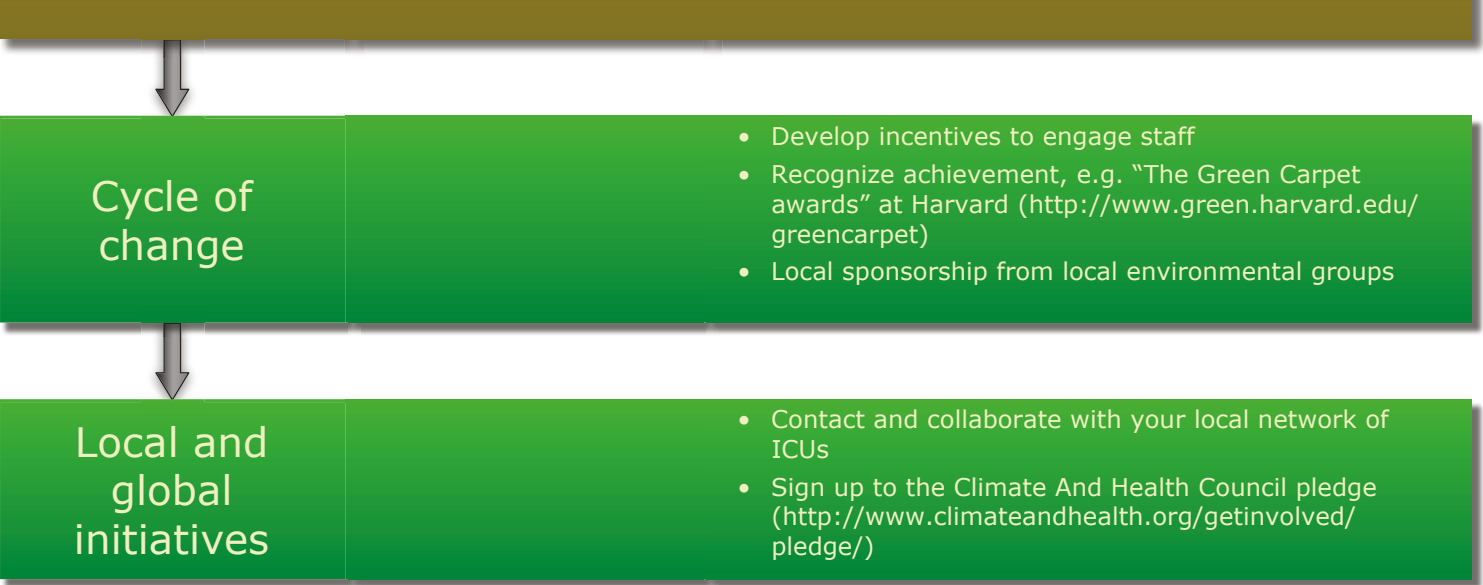

Figure 2. Agenda of environmental stewardship. 


\section{For light relief \\ Carbon Addict - Medical Management for the Carbon Dependence Syndrome [http://www.carbonaddict.org/]}

Abbreviations

GHG, greenhouse gas; ICU, intensive care unit.

\section{Competing interests}

AC was a director for Environmental Defence, a Toronto-based environmental action organisation. MC declares that he has no competing interests

\section{Acknowledgements}

Thanks to Dr Neill Adhikari for his editorial comments and counsel.

\section{Author details}

'Department of Critical Care Medicine, Sunnybrook Health Sciences Centre, Rm D108, 2075 Bayview Avenue, Toronto, Ontario, Canada, M4N 3M5.

${ }^{2}$ Freelancer, Department of Critical Care Medicine, Sunnybrook Health Sciences Centre, Rm D108, 2075 Bayview Avenue, Toronto, Ontario, Canada, M4N 3M5.

\section{Published: 15 March 201}

\section{References}

1. Copenhagen Accord [http://unfcc.int/files/meetingscop_15/application/ pdf/cop15_cph_auv.pdf]

2. Wilks M: 'Greenwash' at the climate change summit in Copenhagen. BMJ 2009, 339:b5616.

3. Rao M: Climate change is deadly: the health impacts of climate change. In The Health Practitioner's Guide to Climate Change. Edited by Griffiths J, Adshead F, Rao M, Thorpe A. London: Earthscan; 2009:33-62.

4. Shuman EK: Global climate change and infectious diseases. N Engl J Med 2010, 362:1061-1063.

5. Greer A, Ng V, Fisman D: Climate change and infectious diseases in North America: the road ahead. CMAJ 2008, 178:715-722

6. Stern Review on the Economics of Climate Change [http://webarchive. nationalarchives.gov.uk/20100407010852/http://www.hm-treasury.gov.uk/ sternreview index.htm]

7. India says Kyoto Climate Pact in 'Intensive Care' [http://blogs.reuters.com/ krittivas-mukherjee/page/11/]

8. Issues: Green Purchasing [http://www.noharm.org/us_canada/issues/ purchasing/]

9. Sustainable Development Commission, Stockholm Environment Institute: NHS England Carbon Footprinting Report. London: Sustainable Development Commission; 2008. [http://www.sd-commission.org.uk/publications/ downloads/NHS_Carbon_Emissions_modelling1.pdf]

10. Roberts Environmental Center: Sustainability Reporting of the World's Largest Pharmaceutical Companies. Claremont, CA: Claremont McKenna College; 2009. [http://www.roberts.cmc.edu/PSI/PDF/Pharmaceuticals2009.pdf]

11. Pancheon D: How health services can act. In The Health Practitioner's Guide to Climate Change. Edited by Griffiths J, Adshead F, Rao M, Thorpe A. London: Earthscan; 2009:295-328.

12. P4CR Procuring for Carbon Reduction [http://www.sdu.nhs.uk/page. php?page_id=159]

13. Kwakye G, Pronovost P, Makary M: Commentary: a call to go green in health care by reprocessing medical equipment. Acad Med 2010, 85:398.

14. The Reprocessing Report: Hospitals Benefit from Sustainability Initiatives with more than \$138 Million in Savings in 2008 [http://www.ascenths.com/ docs/Ascent_Rr_Feb09_SpecialEdition.pdf]
15. Reprocessed Single-use Medical Devices: FDA Oversight has Increased, and Available Information does not Indicate that use Presents an Elevated Health Risk. Washington, DC: US Government Accountability Office; 2008. [http://www. gao.gov/new.items/d08147.pdf]

16. Webster $P$ : Canadian hospitals call for restrictions on single-use devices. Lancet 2004, 363:542.

17. Department of Health: Single-use Medical Devices: Implications and Consequences of Reuse. London: Medicines \& Healthcare Regulatory Agency; 2006. [http://www.mhra.gov.uk/Publications/Safetyguidance/ DeviceBulletins/CON2024995]

18. Winter $\mathrm{A}$ : The future of medical informatics. Methods Info Med 2009 , 48:62-65.

19. Strata Green IT certificate, CompTIA Inc. [http://www.comptia.org/ certifications/strata/ greenit.aspx]

20. Energy Efficiency Opportunities In Ontario Hospitals [http://www.oha. com/Currentlssues/Issues/eHealth/Documents/ EnergyEfficiencyOpportunitiesfeb28.pdf]

21. Waste Reduction - Why Focus on Waste? [http://cms.h2e-online.org/ee/ waste-reduction/]

22. Harvard Medical School Current Energy Usage [https://facilities.med harvard.edu/ENERGY]

23. Leadership in Energy and Environmental Design, Canada Green Building Council [http://www.cagbc.org/Content/NavigationMenu/Programs/LEED/ default.htm]

24. Issues: Toxic Materials. Health Care Without Harm [http://www.noharm. org/us_canada/issues/toxins/

25. Why Health Care is Moving Away from the Hazardous Plastic Polyvinyl Chloride (PVC) [http://www.noharm.org/lib/downloads/pvc/Moving_Away_ from_PVC.pdf]

26. Safety Assessment of Di(2-ethylhexyl)phthalate (DEHP) Released from PVC Medical Devices. Rockville, MD: Center for Devices and Radiological Health; 2002. [http://www.fda.gov/downloads/MedicalDevices/ DeviceRegulationandGuidance/GuidanceDocuments/UCM080457.pdf]

27. Footprint calculator, World Wildlife Foundation [http://wwf.panda.org/ how_you_can_help/live_green/footprint_calculator/]

28. Stewart L, Maryon-Davis A: How you can make a real difference. In The Health Practitioner's Guide to Climate Change. Edited by Griffiths J, Adshead F, Rao M, Thorpe A. London: Earthscan; 2009:197-224.

29. Greenhouse Gas Division, Environment Canada: National Inventory Report: Greenhouse Gas Sources and Sinks in Canada 1990-2005. Gaitineau, Quebec: Government of Canada Publications; 2007. [http://publications.gc.ca/ pub?id=324441\&s $=0]$

30. Support Alternatives to Owning and Driving a Car [http://www davidsuzuki.org/what-you-can-do/reduce-your-carbon-footprint/ support-alternatives-to-owning-and-driving-a-car/]

31. Greenwashing Report 2009 [http://sinsofgreenwashing.org/?dl_id=2]

32. Crane J Caldwell B: Another inconvenient truth? BMJ 2006, 333:1256.

33. Griffiths J, Reynolds L: How to help organizations to take action. In The Health Practitioner's Guide to Climate Change. Edited by Griffiths J, Adshead F, Rao M, Thorpe A. London: Earthscan; 2009:264-294.

34. Uniforms and Workwear: Guidance on Uniform and Workwear Policies for NHS Employers. Leeds: Department of Health; 2010. [http://www.dh.gov.uk/en/ Publicationsandstatistics/Publications/PublicationsPolicyAndGuidance/ DH_114751]

doi:10.1186/cc9409

Cite this article as: Chapman M, Chapman A: Greening critical care. Critical Care 2011, 15:302. 